\title{
Eco-designed Heat Insulating Panels: Experimental Development for Social Houses in an Arid Area of Argentina
}

\author{
By Arturo F. Buigues Nollens*
}

\begin{abstract}
This paper focuses on the design and development of the heat insulating panels that use as filling a local volcanic material called Pomeca Puzolanica. The object of this group of processes is to analyze and apply a system of ventilated façades in the cooling of the Social Houses. This is achieved under the minimum quality standards in the Cuyo Arid Area of San Juan, Argentina. The methodology used in the experimental development of heat insulating panels for thermal conditioning of social houses in Arid and Seismic Areas, includes managing the design and development of the product, during the following stages: in the Design Stage, by establishing objectives, considering the differences which originated this Proposal with Eco-design; in the Manufacturing Stage, by focussing sustainability problems in the generation of Alternatives and Pilot Models for future testing; and in the Testing Stage, by analyzing experiments or simulations and by evaluating results. A Sustainable Technological Solution is obtained from this transformation using a local insulating material, under the 14006 ISO Standard at every life-cycle stage. Its thermal behavior shows convenient results which have been verified by an electronic system of climatic measurements for sensing their variations, thus contributing to the Rational Use of Energy during their life-cycle.
\end{abstract}

\section{Introduction}

At the present, very cold and rigorous winters occur in the arid areas where users of social houses $(\mathrm{SH})$ must undergo critical situations due to thermal needs. This is why some of them use and even depredate wood with a negative impact on the environment's resource.

Besides, summers are very hot, with extreme maximum temperatures, low humidity with a high level of thermal amplitude and a high solar radiation. All this leads to rate highly the important role played by heat insulation.

With heat insulation it is possible to solve the needs of thermal conditioning, avoiding heat losses or gains, according to the time of the year or during adverse climate. It also contributes to indoors decontamination when there is wood smoke, with the possibility of saving and having a Rationally Energy Use (REU) throughout the year, something necessary in San Juan, Argentina. ${ }^{1}$ Besides, the arid San Juan is the province with the highest seismic

* Professor, San Juan National University, Argentina.

1. V. Volantino, P. Bilbao, P. E. Azqueta, P. Bittner, A. Y. Englebert and M. Schopflocher, "Ahorro energético en el consumo de gas residencial mediante aislamiento térmico en la construcción. Unidad Técnica Habitabilidad Higrotérmica" [Energy saving in domestic gas consumption by thermal insulation in construction. Technical Unit: Hygrometric 
hazard of the country. Earthquakes of high magnitude in the Richter scale ${ }^{2}$ have occurred.

Generally in SH expanded polystyrene or EPS is used as a thermal insulating material, nearly always included in bulk or in plates in the roof covers, depending on the design, shape and location. It is also applied indoors in sheets or mounted as ceilings. This material of synthetic inflammable origin has high manufacturing costs between 75 to $125 \mathrm{KJ} / \mathrm{Kg}^{2}$.

These roofs do not generally have the appropriate thickness and especially the vertical enclosures lack the heat insulation, therefore, an improvement by means of an Eco-design with Thermal Insulated Panels (TIP) is justified. It is necessary to develop more complex construction and enveloping techniques than those used for the roofs.

In order to produce an insulating material with low energy costs and with a REU considering an Eco-design for arid areas, the possible availability of literature with recommendations for the application of this kind of products was researched.

Several publications on Energy Rehabilitation were found about existing and new buildings and houses: some international ones such as "Environmental Improvement Potentials of Residential Buildings (IMPRO-Building)" "4 included in the Scientific and Technical Reports. This is a report which gives a general systematic vision of the environmental impacts of the life-cycles of residential buildings in the EU-25 (European Union - 25). They present an analysis of the options of technical improvement which could reduce environmental impacts, paying special attention to its main source, the use of energy for heating. The report evaluates the environmental benefits and the costs associated to the improvements.

Besides, the $\mathrm{IHOBE}^{5}$ has published as Good Practices, 13 practical cases of environmental excellence in Euskadi. Here the Buildings and

Inhabitability,] Instituto Nacional de Tecnología Industrial INTI Construcciones. Comisión de trabajo URE en edificios. AVERMA 11, (2007): 08.123-08.130.

2. INPRES, Zonificación Sísmica, Nuevo Reglamento INPRES CIRSOC 2013. Reglamento Argentino para Construcciones Sismorresistentes [Seismic zonification, New Regulations INPRES CIRSOC 2013. Argentine Regulations for Seismo-resistant buildings] (Argentina: Instituto Nacional de Prevención Sísmica Secretaría de Obras Públicas - Ministerio de Planificación Federal, Inversión Pública y Servicios, 2013), 13-45.

3. A. Bano Nieva, E. Vigil and A. Del Pozo, Materiales de Construcción Sostenible. Los metales. Guía de construcción sostenible [Sustainable Building Materials. Metals. Sustainable Building Guide] (Spain: Instituto Sindical de Trabajo, Ambiente y Salud (ISTAS), 2005), 31-40.

4. F. Nemry, A. Uihlein, C. Makishi Colodel, B. Wittstock, A. Braune, C. Wetzel, I. Hasan, S. Niemeier, Y. Frech, J. Kreißig and N. Gallon, Potenciales de Mejora Medioambiental de los Edificios Residenciales (IMPRO-Building) [Environmental Improvement Potentials of Residential Buildings (IMPRO-Building)] (Luxembourg: Oficina para Publicaciones Oficiales de las Comunidades Europeas. Comunidades Europeas. Centro Común de Investigación de la Comisión Europea. Instituto de Prospectiva Tecnológica, 2008), 1-103.

5. IHOBE, Edificación y Rehabilitación Ambientalmente Sostenible en Euskadi, 13 casos prácticos de excelencia ambiental [Environmentally Sustainable building and rehabilitation in Euskadi. 13 practical cases of environmental excellence] (Bilbao, Spain: Sociedad Pública de Gestión Ambiental, del Departamento de Medio Ambiente y Política Territorial Gobierno Vasco, 2014). 
Environmentally Sustainable Rehabilitations demonstrate that an eco-designed building, constructed under sustainable parameters, objectively achieves better environmental behaviors during its whole life-cycle. In terms of energy efficiency it can reach savings of up to $45 \%$, with a return period of more than five years.

On the other hand, in another publication belonging to the Zaragoza University Press, under the title: Eco-design in Building ${ }^{6}$ (Energy Efficiency Series) the analysis of the life-cycle of the building materials was found. This approach helps decision-taking based on the available technological improvements and the minimization of the environmental impact of buildings based on the design and the rehabilitation.

Developing a green building assessment tool for developing countries ${ }^{7}$ was consulted where these methods of sustainable evaluation of houses ${ }^{8}$ were applied.

There is also a paper on building enveloping, from the Technological Center of Efficient Rehabilitation - Building Area - Energy Labs, Vigo, Pontevedra (2012). The implementation of efficient and renewable technologies in building rehabilitation ${ }^{9}$ has been obtained from the Actuation Protocols and the use of thermal insulation in houses and in façades from the Universidad Politécnica de Valencia. ${ }^{10}$

On the other hand, papers related to Products and Materials and their Thermal Insulating Properties were found at the Instituto Valenciano de la Edificación, Spain ${ }^{11}$ and Guidelines for the use of Ecodesign in Present Systems of Environmental Management were obtained from the International Organization of Normalization in Switzerland.

The School of Architecture and Urbanism of Cuenca (Ecuador) 2015 deals with evaluating the sustainability of building materials. ${ }^{12}$

6. I. Zabalza Bribian, Aranda Usón A. Ecodiseño en la edificación. Serie Eficiencia Energética [Ecodesign in building. Energy Efficiency Series] (Spain: Prensas de la Universidad de Zaragoza, 2011), 50-63.

7. H. Hikmat, A. Ali, F. Saba and B. Al Nsairat, "Developing a green building assessment tool for developing countries, Case of Jordan," Building and Environment. Elsevier 44 (2009): 1053-1064.

8. M. F. Quesada, "Métodos de evaluación sostenible de la vivienda: Análisis comparativo de cinco métodos internacionales" [Methods of sustainable evaluation of houses: Comparative analysis of five international methods,] Revista Hábitat Sustentable 4, no. 1 (2014): $56-67$.

9. I. Bangueses, La envolvente de edificios de los edificios. Protocolos de actuación para la implantación de tecnologías eficientes y renovables en la rehabilitación de edificios [Building enveloping. Actuation protocols for the implementation of efficient renewable technologies in building rehabilitation] (Vigo Pontevedra, Spain: Centro Tecnológico de Rehabilitación Eficiente-Área de edificación-Energy Labs, 2012), 106-115.

10. N. Pascual Roman, La Eficiencia Energética en el Uso de la Vivienda. Factores Incidentes [Energy efficiency in house use. Incidental factors,] Master Thesis (Spain: Polytechnic University of Valencia, 2014), 40-62.

11. IVE, Productos y Materiales. Propiedades de Aislantes Térmicos para Rehabilitación Energética [Products and Materials, Properties of Thermal Insulators for Energy Rehabilitation] (Spain: Instituto Valenciano de la Edificación, 2011), 1, 3-4.

12. Ibid. 
Speaking of San Juan, Argentina, standards were obtained from the Instituto Argentino de Racionalización de Materiales. ${ }^{13}$ It must be mentioned that presently IRAM is revising the 15392 ISO Standard of Sustainability. ${ }^{14}$

For Energetic Rehabilitation of new and existing buildings and houses, international and national standards were found, such as the standards of the Instituto Argentino de Racionalización de Materiales (Argentine Institute of Material Rationalization), now called the Instituto Argentino de Normalización y Certificación (Argentine Normalization and Certification Institute). ${ }^{15}$ It must be mentioned that IRAM is now revising the ISO 15392 Sustainability Standards. ${ }^{16}$

In Figure 1 Sustainability and coverage, according to Standard 14006 and IRAM, considering the aspect of Materials and Resources under the VERDE Certification (Valoración de Eficiencia de Referencia de Edificios - Valuation of Building Reference Efficiency) developed by the Council of Spain's Sustainable Building appear integrated. ${ }^{17}$

13. IRAM 11601, Aislamiento térmico de edificios. Métodos de Cálculo. Propiedades térmicas de los componentes y elementos de construcción en régimen estacionario. Tabla de Conductividades Térmicas [Thermal insulation of buildings. Calculation method. Thermal properties of the building components and elements in a stationary regime. Table of Thermal Conductivities] (Argentina, 2002), 14-20; IRAM 11603, Acondicionamiento Térmico de Edificios. Clasificación bioambiental de la Argentina [Thermal conditioning of buildings. Bioenvironmental Classification of Argentina] (1996), 1-47; IRAM 11605, Acondicionamiento Térmico de Edificios. Condiciones de habitabilidad en edificios. Valores máximos de transmitancia térmica en cerramientos opacos [Thermal conditioning of buildings. Habitability conditions in buildings. Maximum values of thermal transmittance in opaque closures] (1996), 1-27.

14. ISO 15392, Sustainability in building construction - General principles (Ginebra, Switzerland: International Organization for Standardization, 2008).

15. IRAM, Loc. Cit. 10, 11, 12.

16. ISO, Loc. Cit. 13.

17. ATECOS, Certificación Verde, Materiales Aislantes Térmicos. Asistente Técnico para la Construcción Sostenible [Verde Certification (Valuation of Building Reference Efficiency). Insulating thermal materials. Technical assistant for Sustainable Construction] (Spain: Entorno-BCSD Foundation, Foundation of the Autonomous University of Madrid (FUAM) and Miliarium.com, 2010). 


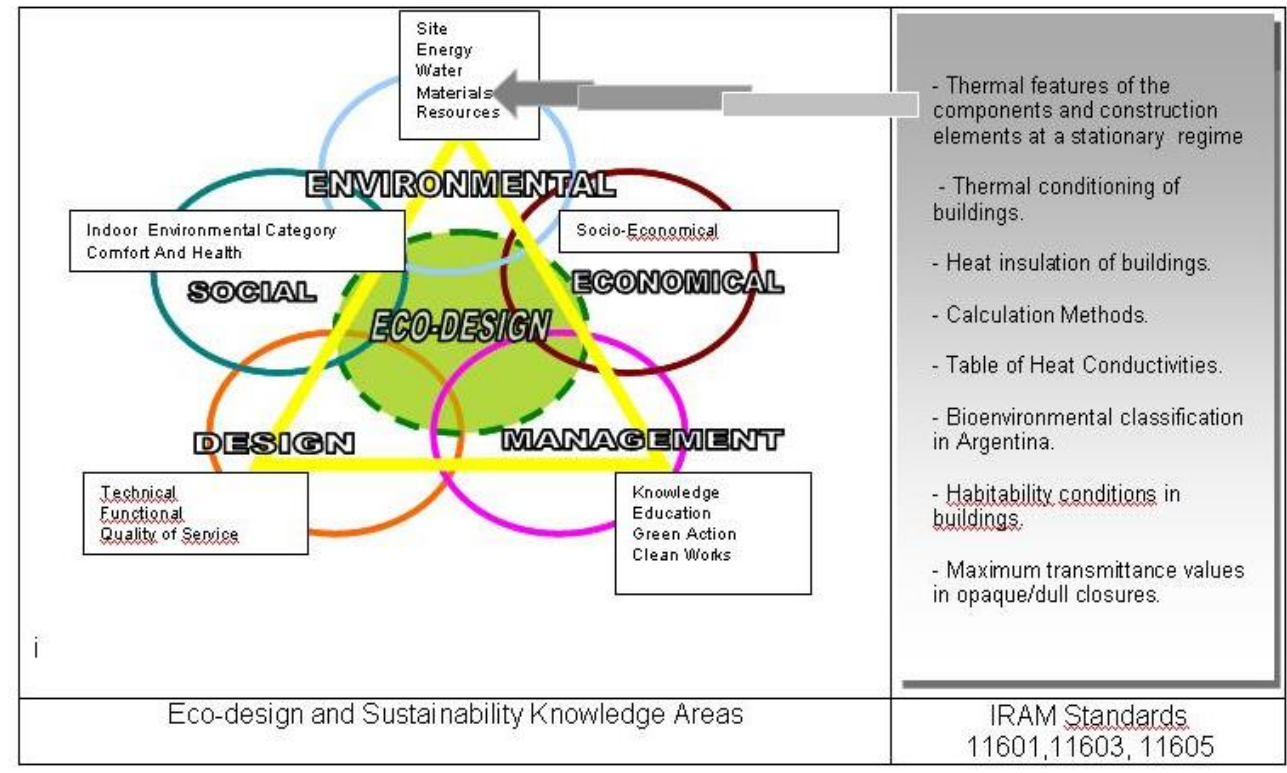

Figure 1. Sustainability and Coverage Dimensions in relation to Materials and Resources

Source: Author Dr. Arturo F. Buigues Nollens.

\section{Objectives}

The activity of the $1^{\text {st }}$ Stage or Design Stage of an exterior ventilated façade system with mineral wool for the Rehabilitation of SH by TIP includes the analysis and experimental application using Pomeca Puzolánica (PP) as heat insulation. Its general objective is to contribute to RUE during its life cycle (LC) for use in SH under minimum quality Standards, in the Cuyo Arid Area, San Juan Province, Argentina. ${ }^{18}$

The specific objectives are: to apply the criteria and associated measures of a sustainable evaluation derived from international methods ${ }^{19}$. Here, the issue of reducing environmental impact is considered at the Design, Manufacturing and Testing Stages of the solar Thermal Panels with PP. Other objectives are the reduction of environmental impact taking into consideration the following aspects: reduction of the amount of non-renewable energy used in transport, promoting the use of a local building material of volcanic origin; reduction of the impact associated to the consumption of non-renewable energy by selecting material with low energy consumption during the extraction and

18. SSDUV, Estándares Minimos de Calidad para Viviendas de Interés Social Revisión 2006. Documento Técnico: Acondicionamiento Higrotérmico [Minimum Quality Standards for SH. 2006 Revision. Technical Document: Hygrometric Conditioning] (Argentina: Dirección de Tecnología y Producción Ciudad de Buenos Aires. Subsecretaría de Desarrollo Urbano y Vivienda. Secretaría de Obras Públicas. Ministerio de Planificación Federal, Inversión Pública y Servicios, 2006), 12- 27; Hikmat, "Developing a green building assessment tool for developing countries, Case of Jordan," 6.

19. Quesada, "Métodos de evaluación sostenible de la vivienda: Análisis comparativo de cinco métodos internacionales," 5. 
transformation process and by the use of reused or recycled materials; reduction of the residues generated during the rehabilitation, with the use of the pre-manufactured and industrialized elements; and use of control processes with minimum residues. ${ }^{20}$

\section{Methods}

The methods used in the experimental development of heat insulating panels for the thermal conditioning of SH for the inhabitants of Arid and Seismic Areas include: managing the design and development process of the product $^{21}$ during the following stages, Design: establishing objectives considering the differences which originate the Ecodesign Proposal; Manufacturing: focussing the Sustainability problems in the generation of Alternatives and of Pilot Models in order to be tested and in the Testing Stage: Realization of Experiments or Simulations and evaluations of their results.

This process makes the production of TIP a Sustainable Technological Solution which is an insulating local material, under the 14006 ISO Standard throughout all the stages of the LC. ${ }^{22}$ Its thermal behavior produces results which are verified by a climate electronic system which measures its variations. During these measuring campaigns performed at the IMA lab, which includes similar rooms to those of the $\mathrm{SH}$, exposed to arid climate, various activites related to the distribution, positioning, calibration and installation of sensors; determination of the reading frequency, saving and installation of the electronic data acquisition system were carried out. Advanced trend and analysis software for plotting information in real time was used.

\section{Developed Stages or Activities}

In the Design Stage after establishing the objectives of the Design with PP, the following activities will take place in the $2^{\text {nd }}$ Manufacturing Stage in order to obtain more Sustainable Technology.

Activity 1: Transport of the Insulating Material Considering a Reduced Amount of Non-renewable Energy

20. ATECOS, Certificación Verde, Materiales Aislantes Térmicos. Asistente Técnico para la Construcción Sostenible, 16.

21. F. Miranda, La gestión del proceso de diseño y desarrollo de productos [Management of the process of product design and development] (Economía de la Empresa, 2000), http:// www.5campus.com/leccion/desapro, [accessed 07/10/2014].

22. ISO 14006, Sistemas de gestión Ambiental. Directrices para la incorporación del ecodiseño [Environmental management systems. Guidelings for the incorporation of Ecodesign] (Switzerland: 2011), 1-15. 
Pumice stone occurs in mantles of variable thicknesses, in some cases, 3 or $4 \mathrm{~m}$ deep. It is extracted after a previous cleaning of the materials it covers. This is performed with front chargers which place it on sieves for the cleaning process of the material, eliminating sand and tuff.

Once this has been completed, the stone is transported to the plant to be ground and classified by size. Most plants are found at the same sites.

Thus PP is extracted naturally and from open pits at the Pumice quarry, without having to use non - renewable energies as gas IDR, 1998 in the process. ${ }^{23}$ Later, it is transported on semi trailer trucks $270 \mathrm{~km}$ to the city of San Juan from San Carlos in Mendoza where there is a renewable production of 20,000 tons per year. PP is taken to industries or yards and unloaded following the regulations of the San Juan Capital Department deposits or sheds which consist of a metal structure. Here, the PP is mobilized and stored with a small power shovel. It is distributed in the truck according to the demand and it is prevented from being blown by a canvas cover during its transport to the works or factory where it is unloaded (see Figure 2).

\section{Activity 2: Use of a Low Energy-consumption Constructive Technique during the Transformation Process}

Complying with the modular coordination of a wall made of locked concrete blocks, this proposal limits heat transfer by means of a system which has been developed taking in consideration a series production for façade coating, given the needs to contain and protect the thermal insulation and provide a finishing according to the different design alternatives of the finished or future houses.

The building technology used in this system consists in the use of the PP thermal insulation on the outside of the supporting wall (existing façade), an air chamber or tube where air circulates by simple convection and a protection of an outer light sheet, insulated with PP. The outer insulating system is being increasingly used due to its excellent energy savings during the hot periods of the year. The protection film or sheet is fixed to the wall by substructures designed for that purpose.

This system plus the ventilation conditions contribute to the elimination of indoor health problems, such as dampness and condensation. The materials used are removable and recyclable/reusable. ${ }^{24}$

A previous preparation of the external surface of the wall (stripped, repaired, etc) is not necessary. It allows optional installations between the chamber and the insultating material. The external ventilated air chamber protects the insulating material and the wall support from the weather

23. IDR, Caracterización Minera de la Provincia de Mendoza [Mining Characterization of the province of Mendoza] (Argentina: Subsecretaria de Programación Económica-Instituto de Desarrollo Rural-Ministerio de Economía Gobierno de Mendoza, 1998), 123-129.

24. FENERCOM, Fundación de la Energía de la Comunidad de Madrid. Guía de rehabilitación energética de edificios de viviendas Madrid [Foundation of the Community Energy of Madrid. Energy rehabilitation Guide of buildings in Madrid] (Spain: Madrid Vive Ahorrando Energía, 2008), 33-36. 
conditions (water, sun, wind, etc.). The PP has been analyzed in a lab following IRAM standards by an Rx diffraction analysis and an optical observation at the Instituto de Investigaciones Mineras (Mining Research Institute) of the School of Engineering, UNSJ. The results of this analysis confirmed that the minerals (quartz, feldspar, calcite and mica and biotita) present an important crystalline structure which can be detected by this method. The percentage of presence of insulating minerals, such as glass is high. ${ }^{25}$

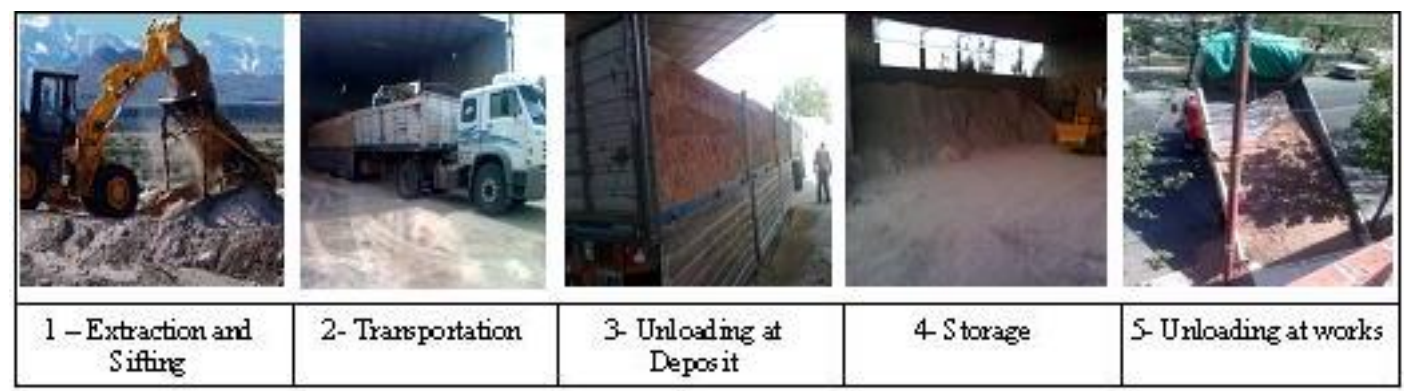

Figure 2. Transport of the Material from the Extraction Plant to the Processing Site

Source: Author Dr. Arturo F. Buigues Nollens.

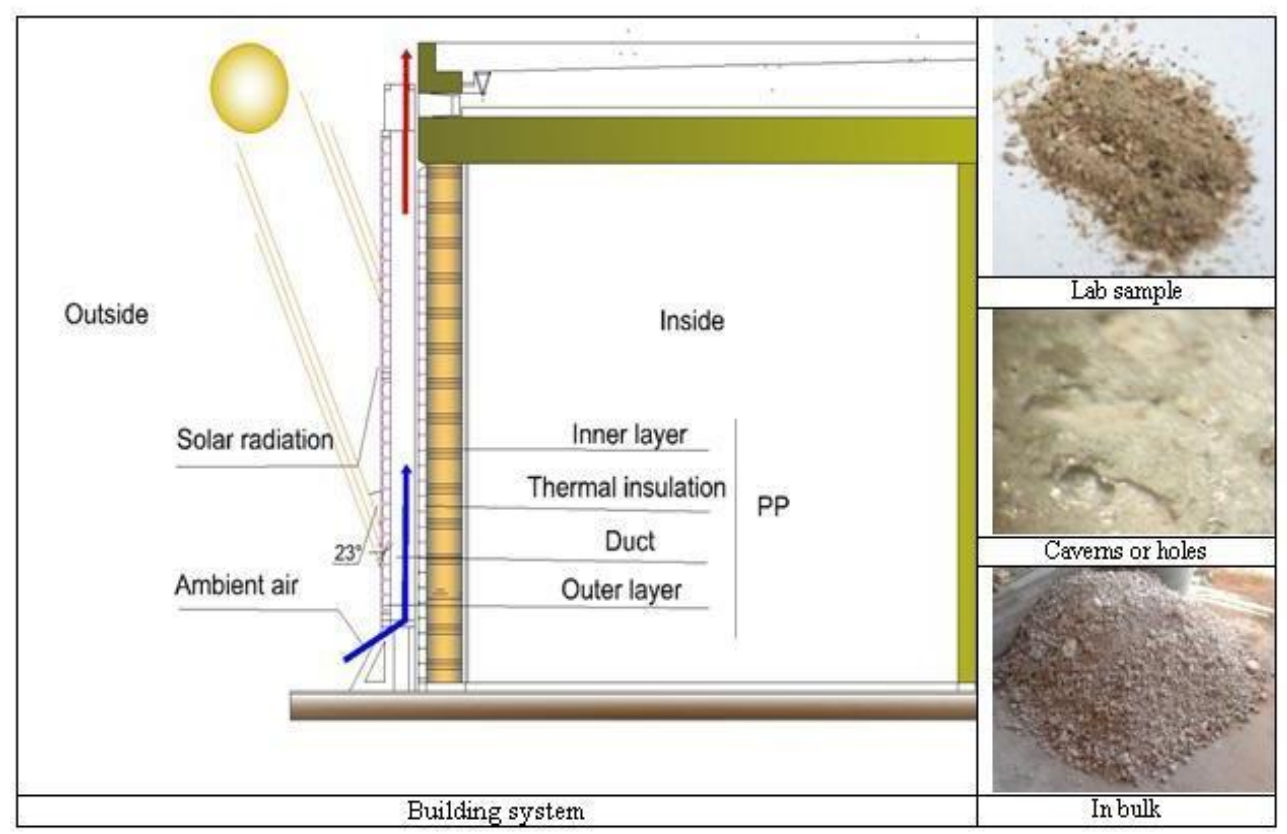

Figure 3. General Characteristics of the Panel and of the Heat Insulating Filling

Source: Author Dr. Arturo F. Buigues Nollens.

25. A. F. Buigues Nollens, "Aprovechamiento de la Pomeca Puzolánica en Envolventes. Desarrollo Experimental de un Panel Termoaislante para Viviendas de Zonas Áridas en Argentina" [Utilization of Pomeca Puzolánica in Enveloppings. Experimental Development of a Thermo-insulating Panel for houses in arid areas of Argentina,] Revista Hábitat Sustentable 3, no. 1 (2013): 62-71. 
This allows the determination that in PP there are a total of $66 \%$ presence of insultating minerals plus the existence of caverns or holes.

Thus PP can be used in bulk as filling, according to the way in which it is produced at the deposit and without any industrial process or later transformation (see Figure 3).

This insulating filling is complemented with a white "skin", to increase the reduction of thermal exchange between the exterior and the interior. The energy production cost of an insulating material of volcanic origin, similar to PP is Perlite. This varies from 5 to $20 \mathrm{MJ} / \mathrm{Kg}^{2}$, according to the values obtained from different documented sources. They refer to the energy cost of materials in the raw material extraction manufacturing, transformation and transport. These are associated by the Instituto, Valenciano de la Edificación (Building Institute of Valencia) BIV, $2011^{26}$ (see Figure 4).

Activity 3: Generation of Alternatives with Low Residue Production for the

Use of Pre-manufactured or Industrialized Elements during the Building Process

During the Manufacturing Process different alternatives and variants are generated with the implementation of two modular insulating sheets and their corresponding building systems, which are applied in different ways:

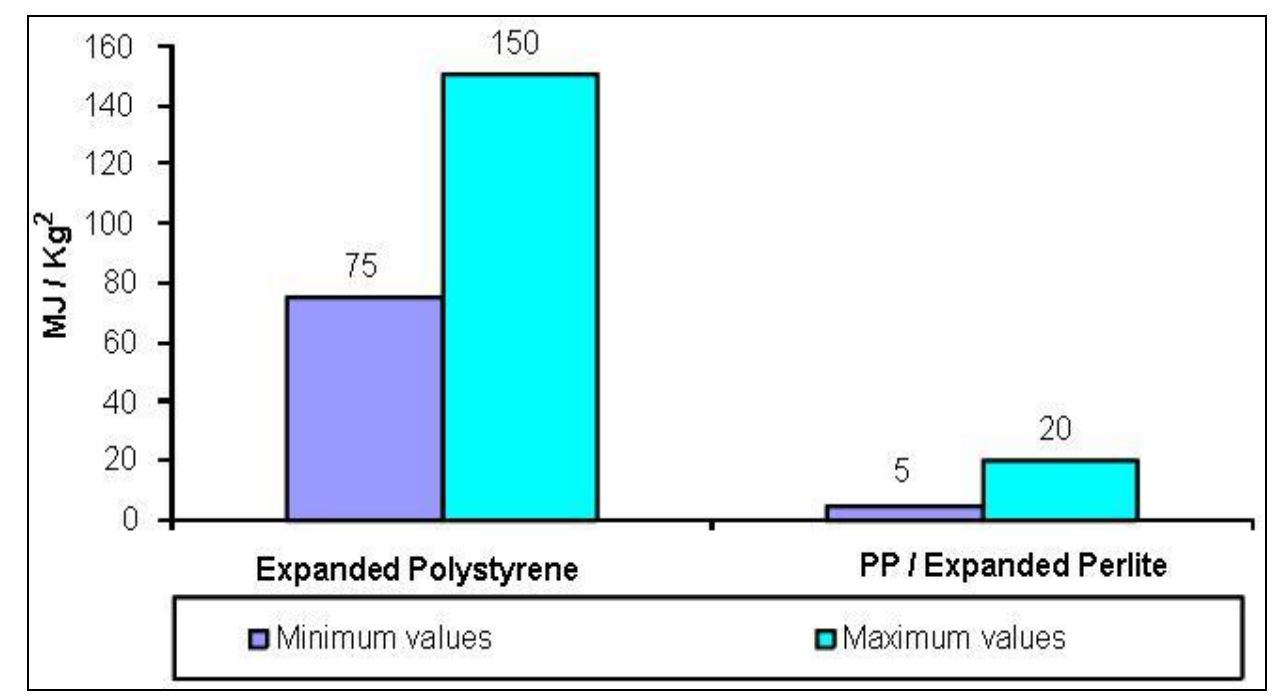

Figure 4. Comparative Analysis of the Production Costs of Expanded Polystyrene and PP or Expanded Perlite. Alternative 1: Directly on the 0.50m x $0.50 \mathrm{~m} \times 0.05 \mathrm{~m}$ Wall

Source: Author Dr. Arturo F. Buigues Nollens.

26. IVE, Productos y Materiales. Propiedades de Aislantes Térmicos para Rehabilitación Energética, 1, 3-4. 
Alternative: Separated from the Wall as a Back Ventilated Tube

$(3.40 \mathrm{~m} \times 1.00 \mathrm{~m})$

This paper does not include the development, which corresponds to the sheet directly applied on the wall. ${ }^{27}$ It presents an alternative with the application of TIP, using the system which is separated from the wall as a back ventilated tube. This tube consists of two layers: internal and external.

The external "skin" has the following characteristics:

- Low specific weight, versatility and adaptability to the possible presence of seismic movements. This is why metals have been selected in this paper and more specifically a steel sheet and laminated black tubes, because they combine endurance with workability for an area with high-magnitude earthquakes. It has a relatively low price which makes its application to SH possible. This made the outer "skin" of both layers to be constructed with double-descaled (DD) black sheets $\mathrm{N}^{\circ} 18$ painted with a white rust converter.

- Mechanical endurance, to contain and protect the PP.

- Minimum residue production of the industrial steel sheet $(1.22 \mathrm{x}$ $2.44 \mathrm{~m})$. This is due to the fact that during the envelope's construction, the longitudinal dimension of the steel sheet was always kept at the panel's height and the panel was reduced longitudinally by only one cut, so as to obtain the tube's width. The intention was to facilitate the reutilization, recovery or the recycling of the original dimension of the steel sheet, at the end of the LC in order to obtain a new product (see Figure 5).

Activity 4: Manufacture of the Model by the Use of Controlled Processes with Minimum Residue Production

In order to reduce the production of residues using layer filling with unsifted PP, as it comes from the quarry, and with sifted PP. Both layers were analysed with the thermal insulating material of volcanic origin by means of the following options of Alternative 2.

27. Buigues Nollens, Loc. Cit. 25. 


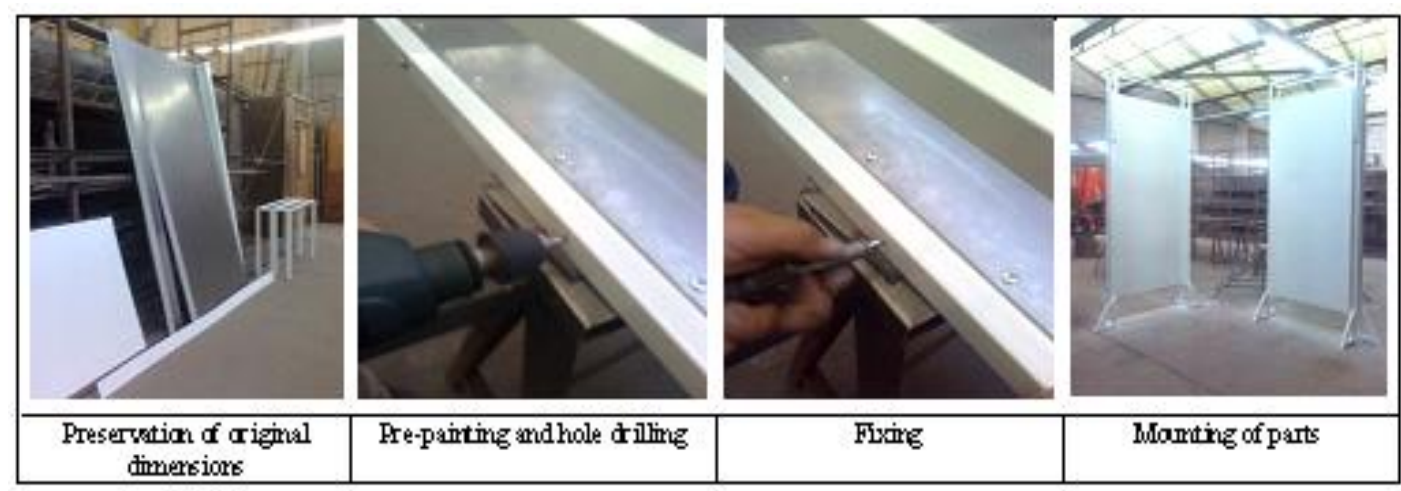

Figure 5. Used Industrialized Elements, Transformation and Termination Process

Source: Author Dr. Arturo F. Buigues Nollens.

Option 1: Without Sifting

As it comes from the quarry, loose, in bulk and without the use of water during the industrial process: The use of PP during its regular application requires the workers' protection from the dust for its distribution and compacting. In order to control the blowing of mineral dust containing PP between the sheet and the structural framework, a sealing joint is applied, (see Figure 6).

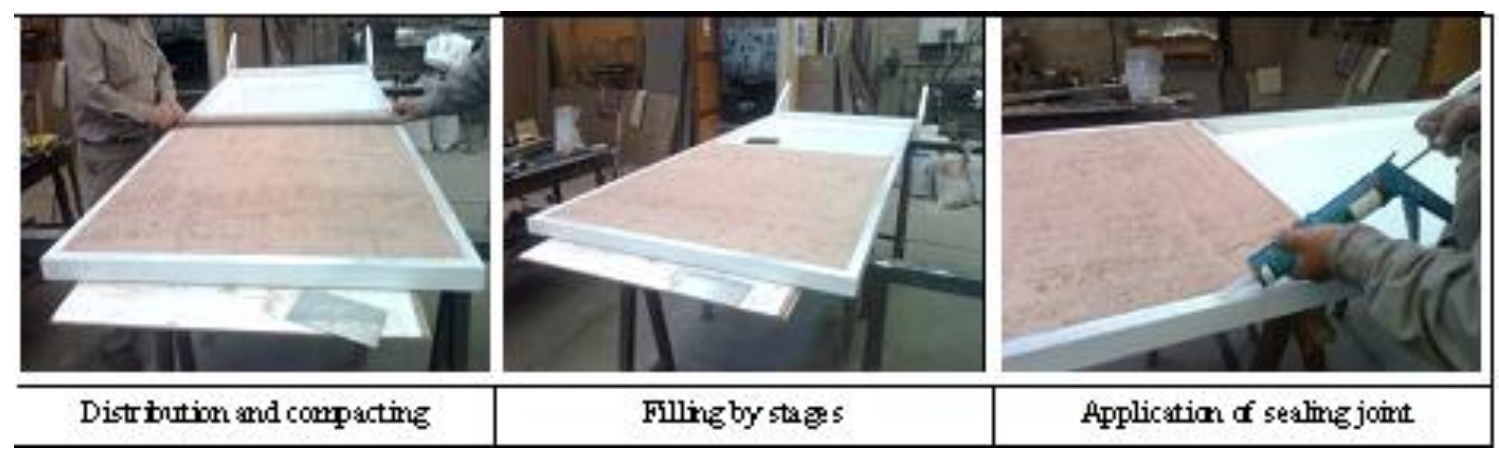

Figure 6. Process of Filling and Finishing for the Final Assembly with Unsifted PP

Source: Author Dr. Arturo F. Buigues Nollens.

Option 2: Sifting

If PP is provided after having been sifted with a minimum pass of $1 \mathrm{~cm}$, the application of the material is improved, avoiding the need of protection from the dust and the use of joints in the envelopping system. The weight is reduced $50 \%$ contributing to a minor overweight of the principal antiseismic structure of the $\mathrm{SH}$.

On the other hand, sifted PP, by having less density, reduces the presence of volcanic earth and its Puzolanic capacity, made up of feldespato and calcite, and it increases its thermal insulating capacity in the filling, as the material thus 
selected has a greater granulometry and contains a greater number of closed and vacant microcells. This material contains a high percentage of biotite and mica, with a thermal endurance similar to that of the loose and granulated Expanded Perlite and which for a density between $30-130 \mathrm{~kg} / \mathrm{m}^{3}$ reaches a thermal conductivity of $0.054 \mathrm{~W} / \mathrm{m}^{2} \mathrm{~K}$. This term which varies between 0.040 $0.060 \mathrm{~W} / \mathrm{mK}$ is assumed as an intermediate value for PP (see Figure 7).

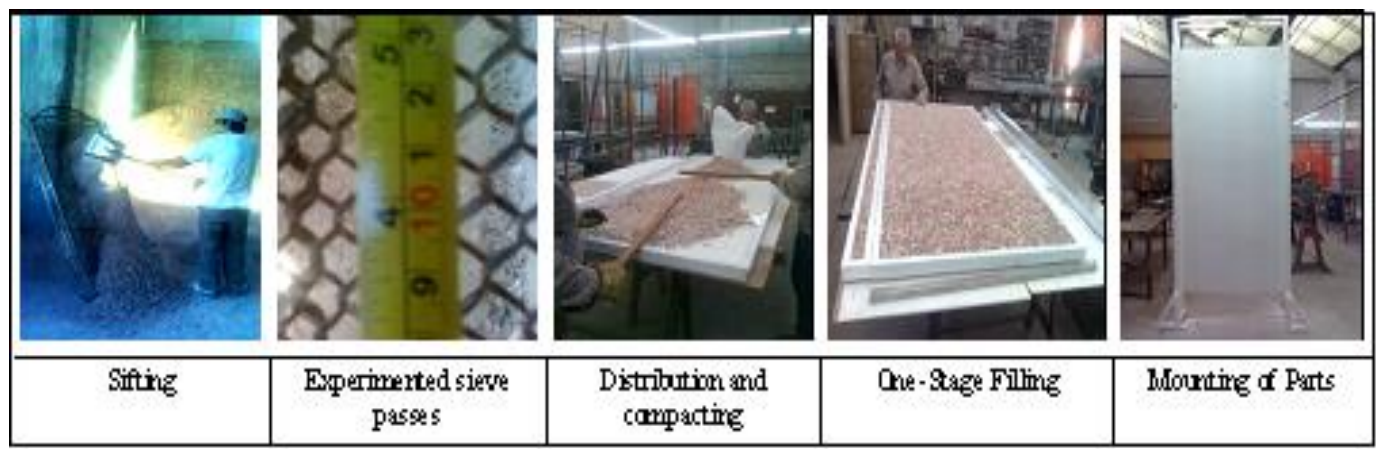

Figure 7. Filling and Finishing Process for the Final Assembly with Sifted PP Source: Author Dr. Arturo F. Buigues Nollens.

\section{Activity 5: Transformation, Assembly and Dismounting}

Inhabitability is the main factor proposed to evaluate and determine the houses quality, as long as inhabitability is understood as depending on the adequate operation of the physical and social supports. It is in the union of both supports that "adaptability" is found.

Therefore the adaptability of a $\mathrm{SH}$, implies processes of functional, morphological and constructive transformations. ${ }^{28}$ The characteristics applied to the manufacture of TIP, to the constructive system and the components used respond to these processes. That is why the following features must be pointed out:

- Transformable: Metals such as steel represent one of the most remarkable examples of materials to be transformed into a new metal, consolidating a transformation circuit of the material due to the high manufacturing cost starting from the raw material.

- This is one of the reasons for the creation of a transformation circuit. ${ }^{29}$

- Assembly and Dismounting: The vertical insulating enveloping system is mounted with a "dry" assembly technique and it consists of industrialized pre-manufactured components without joints. ${ }^{30}$ It is supported by a light structure of black laminated pipes, 30x30 mm wide

28. D. M. Fiscarelli and K. A. Cortina, La adaptabilidad como variable de la calidad de la vivienda. Vivienda, adaptabilidad y criterios proyectuales [Adaptability as a quality variable of houses. Houses, adaptability, Project criteria] (Argentina: $1^{\circ}$ Congreso ALCONPAT Patología, control de calidad y rehabilitación en la construcción, 2013), 12-17.

29. Bano Nieva, Loc. Cit. 3.

30. Ibid, 32-39. 
and $0,9 \mathrm{~mm}$ thick, which independently supports the inner and outer layers which are made up of industrialized steel components in the way of the skin. This skin and the structure are fixed by screws (see Figure $5)$.

\section{Experimental Results}

Thus modules may be transported from the Manufacturing Plant without having to consider delays in the product's drying and in the finishing due to unfavorable climate conditions during the manufacturing process. This happens to the traditional construction when it is taken from the plant to a quick fixing at the site (see Figure 8).

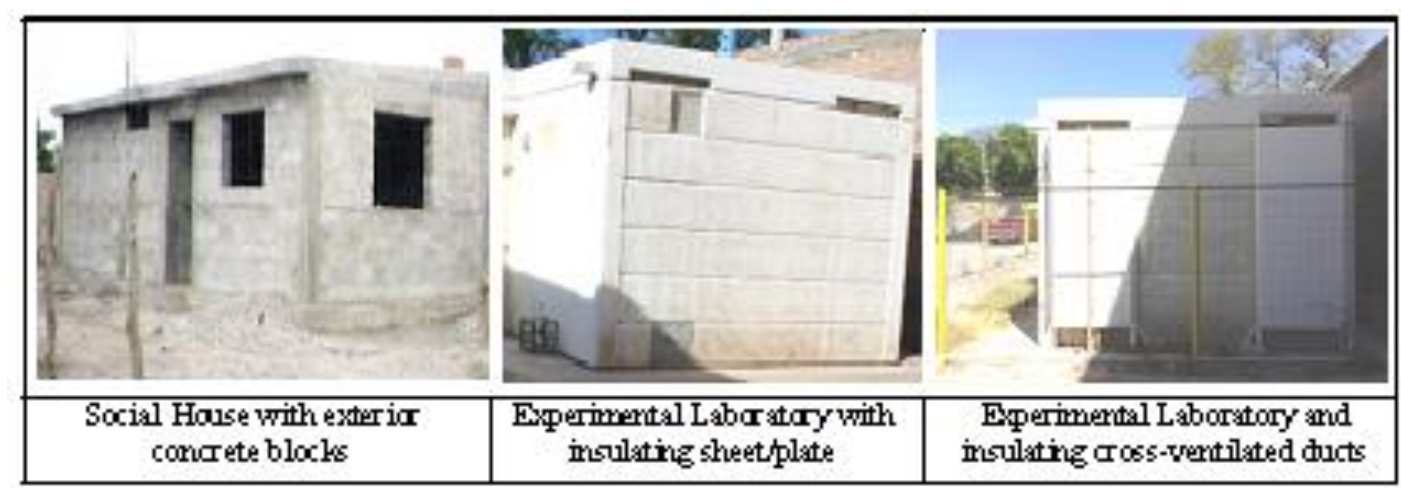

Figure 8. Social House and Verification of Experimental Alternatives Source: Author Dr. Arturo F. Buigues Nollens.

At the Experimental Stage or Third Stage, after having finished the development of Alternative 2 and its options, several measuring campaigns are carried out concerning the TIP's thermal behavior. The design and development has been validated according to the completed stages, and the thermal behavior of Option 1, has been verified. ${ }^{31}$ As was mentioned before this Option was displayed as a back ventilated pipe satisfying the indoor comfort demands in relation to the Summer refreshening of the SH in the Arid Area of San Juan.

In the measuring campaigns performed in the laboratory with experiences in the city of San Juan, during the first days of October 2014, at 2 p.m., having an ambient temperature of $29.4^{\circ} \mathrm{C}$, a relative humidity of $32 \%$, a $10 \mathrm{~km} / \mathrm{h}$ wind speed with an East - Northeast direction, readings of surface and air temperatures were obtained in the North façade from integrated wire LM73 temperature sensors, together with Matlab 7.0.4. The preliminary results indicate the following performance (see Figure 9):

While the outer surface sensors of the Outer Layer which are painted in white and filled with $\mathrm{PP}$ reach between $45^{\circ} \mathrm{C}$ and $50^{\circ} \mathrm{C}$ approximately, the temperature of the inner surface and of the air inside the pipe reaches between

31. ISO, Loc. Cit. 22. 
$35^{\circ} \mathrm{C}$ and $38^{\circ} \mathrm{C}$. And while the air temperature at the pipe exits, it reaches $42^{\circ} \mathrm{C}$, the temperature of the Outer Layer, identified as the outer layer of the wall, varies between temperatures of $25^{\circ} \mathrm{C}$ and $35^{\circ} \mathrm{C}$. The temperature of the inner surface of the block wall varies between $18^{\circ} \mathrm{C}$ and $25^{\circ} \mathrm{C}$.

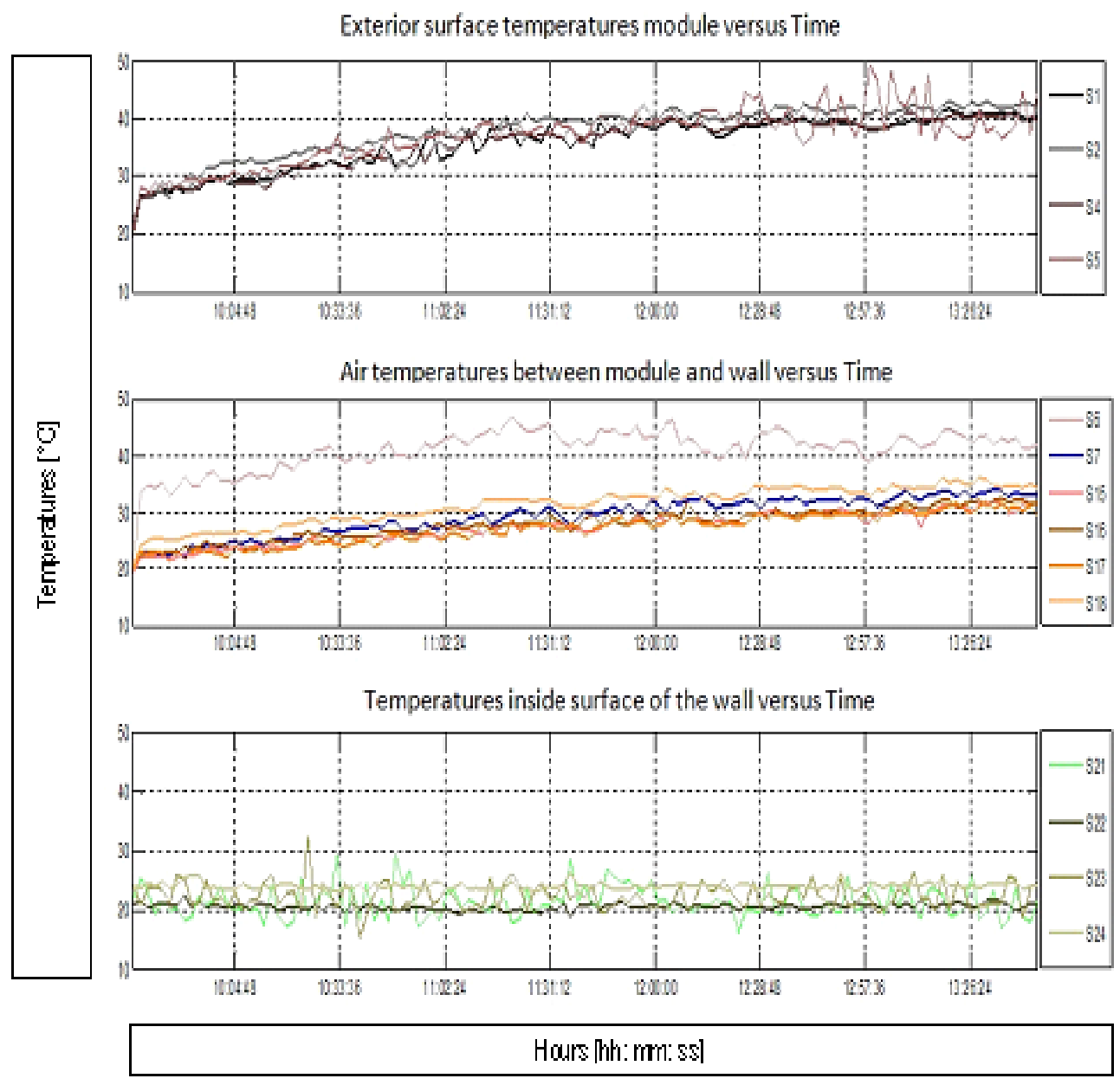

Figure 9. Verification of the Thermal Performance of the North Concrete Block Wall with a Back-ventilated Pipe Isolated with PP Source: Author Dr. Arturo F. Buigues Nollens.

\section{Results and Discussion}

As a Testing Stage and after having finished an alternative and its variants, different measuring campaigns related to the analysis of the PP thermal behavior are carried out.

This $3^{\text {rd }}$ Stage is aimed at validating the design and development, according to the stages that have been carried out and at verifying the thermal behavior of option $1,{ }^{32}$ which was placed as a transventilated pipe for the

32. ISO, Loc. Cit. 22. 
satisfaction of indoor comfort in relation to cooling, during the Summer period of the SH in San Juan, Argentina.

Activities related to the distribution, positioning, calibration and installation of sensors have been carried out. Other activities include the determination of the reading frequency, the saving and installation of the data acquisition system, and the application of the advanced trend and analysis software for the plotting of information in real time.

\section{Conclusions}

In order to contribute to the architectural sustainability of $\mathrm{SH}$, an approximation to the Ecodesign applied to the pilot development of Thermal Insulting Panel Components with ventilated air chamber has been used. The result was an innovating solution to the problem of heat gains by the façades of present or future built houses.

The experimental research which had to validate the design and development verified the insulating capacity and its thermal behavior and demonstrated that the energy flowing inside the spaces, convenientely contributes to thermal comfort.

As it is an energy efficient technology, it permits the thermal Rehabilitation and Cooling of numerous houses of families with low income, satifying inhabitability needs.

This means that this innovating proposal considers not only energy saving but also the dwellers' health and quality of living, thus contributing to adapt man to arid areas in an integral way.

The activities of the different stages prove that research has gone even further than merely complying with an approximation process to ecodesign by redesigning and optimizing the existing product. Experimentation has reached a new product originated in eco-innovation.

Thus it is demonstrated that a technological system, with simple production and construction techniques may be developed. This system uses a local insulating material, of natural origin as a filling in an ecoefficient way. The sustainable characteristics of the components contribute in general to the reduction of costs, of negative emissions and to increase the reutilization and remanufacturing of its elements at the end of the LC.

\section{Acknowledgments}

- Secretaría de Ciencia y Técnica, Rectorado - UNSJ. (Secretary of Science and Technics - Board of Directors - UNSJ).

- Instituto de mecánica Aplicada - IMA, FI, UNSJ, (Institute of Applied Mechanics - School of Engineering. UNSJ) and in particular to Electronic Eng. Leonardo A. Pogrebynski for his collaboration in the display of sensors and the acquisition of thermal data. 


\section{Bibliography}

ATECOS. Certificación Verde, Materiales Aislantes Térmicos. Asistente Técnico para la Construcción Sostenible [Verde Certification (Valuation of Building Reference Efficiency). Insulating thermal materials. Technical assistant for Sustainable Construction.] Spain: Entorno-BCSD Foundation, Foundation of the Autonomous University of Madrid (FUAM) and Miliarium.com, 2010.

Bangueses, I. La envolvente de edificios de los edificios. Protocolos de actuación para la implantación de tecnologías eficientes y renovables en la rehabilitación de edificios [Building enveloping. Actuation protocols for the implementation of efficient renewable technologies in building rehabilitation.] Vigo Pontevedra, Spain: Centro Tecnológico de Rehabilitación Eficiente-Área de edificaciónEnergy Labs, 2012. 106-115.

Bano Nieva, A., E. Vigil and A. Del Pozo. Materiales de Construcción Sostenible. Los metales. Guía de construcción sostenible [Sustainable Building Materials. Metals. Sustainable Building Guide.] Spain: Instituto Sindical de Trabajo, Ambiente y Salud (ISTAS), 2005. 31-40.

Buigues Nollens, A. F. "Aprovechamiento de la Pomeca Puzolánica en Envolventes. Desarrollo Experimental de un Panel Termoaislante para Viviendas de Zonas Áridas en Argentina" [Utilization of Pomeca Puzolánica in Enveloppings. Experimental Development of a Thermo-insulating Panel for houses in arid areas of Argentina.] Revista Hábitat Sustentable 3, no. 1 (2013): 62-71.

FENERCOM. Fundación de la Energía de la Comunidad de Madrid. Guía de rehabilitación energética de edificios de viviendas Madrid [Foundation of the Community Energy of Madrid. Energy rehabilitation Guide of buildings in Madrid.] Spain: Madrid Vive Ahorrando Energía, 2008. 33-36.

Fiscarelli, D. M. and K. A. Cortina. La adaptabilidad como variable de la calidad de la vivienda. Vivienda, adaptabilidad y criterios proyectuales [Adaptability as a quality variable of houses. Houses, adaptability, Project criteria.] Argentina: $1^{\circ}$ Congreso ALCONPAT Patología, control de calidad y rehabilitación en la construcción, 2013. 12-17.

Hikmat H., A. Al, F. Saba and B. Al Nsairat. "Developing a green building assessment tool for developing countries, Case of Jordan." Building and Environment. Elsevier 44 (2009): 1053-1064.

IDR. Caracterización Minera de la Provincia de Mendoza [Mining Characterization of the province of Mendoza.] Argentina: Subsecretaria de Programación Económica-Instituto de Desarrollo Rural-Ministerio de Economía Gobierno de Mendoza, 1998. 123-129.

IHOBE. Edificación y Rehabilitación Ambientalmente Sostenible en Euskadi, 13 casos prácticos de excelencia ambiental [Environmentally Sustainable building and rehabilitation in Euskadi. 13 practical cases of environmental excellence.] Bilbao, Spain: Sociedad Pública de Gestión Ambiental, del Departamento de Medio Ambiente y Política Territorial Gobierno Vasco, 2014.

INPRES. Zonificación Sísmica, Nuevo Reglamento INPRES CIRSOC 2013. Reglamento Argentino para Construcciones Sismorresistentes [Seismic zonification, New Regulations INPRES CIRSOC 2013. Argentine Regulations for Seismo-resistant buildings.] Argentina: Instituto Nacional de Prevención Sísmica Secretaría de Obras Públicas - Ministerio de Planificación Federal, Inversión Pública y Servicios, 2013. 13-45. 
IRAM 11601. Aislamiento térmico de edificios. Métodos de Cálculo. Propiedades térmicas de los componentes y elementos de construcción en régimen estacionario. Tabla de Conductividades Térmicas. [Thermal insulation of buildings. Calculation method. Thermal properties of the building components and elements in a stationary regime. Table of Thermal Conductivities.] Argentina, 2002, 14-20.

IRAM 11603. Acondicionamiento Térmico de Edificios. Clasificación bioambiental de la Argentina [Thermal conditioning of buildings. Bioenvironmental Classification of Argentina.] 1996. 1-47.

IRAM 11605. Acondicionamiento Térmico de Edificios. Condiciones de habitabilidad en edificios. Valores máximos de transmitancia térmica en cerramientos opacos [Thermal conditioning of buildings. Habitability conditions in buildings. Maximum values of thermal transmittance in opaque closures.] 1996. 1-27.

ISO 14006. Sistemas de gestión Ambiental. Directrices para la incorporación del ecodiseño [Environmental management systems. Guidelings for the incorporation of Ecodesign.] Switzerland: 2011. 1-15.

ISO 15392. Sustainability in building construction - General principles. Ginebra, Switzerland: International Organization for Standardization, 2008.

IVE. Productos y Materiales. Propiedades de Aislantes Térmicos para Rehabilitación Energética [Products and Materials, Properties of Thermal Insulators for Energy Rehabilitation.] Spain: Instituto Valenciano de la Edificación, 2011. 1, 3-4.

Miranda, F. La gestión del proceso de diseño y desarrollo de productos [Management of the process of product design and development.] Economía de la Empresa, 2000. http://www.5campus.com/leccion/desapro. [Accessed 07/10/2014].

Nemry F., A. Uihlein, C. Makishi Colodel, B. Wittstock, A. Braune, C. Wetzel, I. Hasan, S. Niemeier, Y. Frech, J. Kreißig and N. Gallon. Potenciales de Mejora Medioambiental de los Edificios Residenciales (IMPRO-Building) [Environmental Improvement Potentials of Residential Buildings (IMPRO-Building).] Luxembourg: Oficina para Publicaciones Oficiales de las Comunidades Europeas. Comunidades Europeas. Centro Común de Investigación de la Comisión Europea. Instituto de Prospectiva Tecnológica, 2008. 1-103.

Pascual Roman N. La Eficiencia Energética en el Uso de la Vivienda. Factores Incidentes [Energy efficiency in house use. Incidental factors.] Master Thesis. Spain: Polytechnic University of Valencia, 2014. 40-62.

Quesada M. F. "Métodos de evaluación sostenible de la vivienda: Análisis comparativo de cinco métodos internacionales." [Methods of sustainable evaluation of houses: Comparative analysis of five international methods.] Revista Hábitat Sustentable 4, no. 1 (2014): 56 -67.

SSDUV. Estándares Mínimos de Calidad para Viviendas de Interés Social Revisión 2006. Documento Técnico: Acondicionamiento Higrotérmico [Minimum Quality Standards for SH. 2006 Revision. Technical Document: Hygrometric Conditioning.] Argentina: Dirección de Tecnología y Producción Ciudad de Buenos Aires. Subsecretaría de Desarrollo Urbano y Vivienda. Secretaría de Obras Públicas. Ministerio de Planificación Federal, Inversión Pública y Servicios, 2006. 12- 27.

Volantino, V., P. Bilbao, P. E. Azqueta, P. Bittner, A. Y. Englebert and M. Schopflocher. "Ahorro energético en el consumo de gas residencial mediante aislamiento térmico en la construcción. Unidad Técnica Habitabilidad Higrotérmica" [Energy saving in domestic gas consumption by thermal insulation in construction. Technical Unit: Hygrometric Inhabitability.] Instituto Nacional 
de Tecnología Industrial INTI Construcciones. Comisión de trabajo URE en edificios. AVERMA 11, (2007): 08.123-08.130.

Zabalza Bribian I. Aranda Usón A. Ecodiseño en la edificación. Serie Eficiencia Energética [Ecodesign in building. Energy Efficiency Series.] Spain: Prensas de la Universidad de Zaragoza, 2011. 50-63. 